\title{
KAJIAN HUKUM KEKERASAN BERBASIS GENDER ONLINE DIHUBUNGKAN DENGAN TUJUAN PEMIDANAAN DALAM PERSPEKTIF NEGARA HUKUM PANCASILA
}

Sahat Maruli Tua Situmeang; Ira Maulia Nurkusumah

Fakultas Hukum Universitas Komputer Indonesia

Email: sahat@email.unikom.ac.id

Naskah dikirim : 27 Juni 2021

Naskah diterima untuk diterbitkan : 27 Juli 2021

DOI : 10.34010/rnlj.v\%vi\%i.5100

\begin{abstract}
The Indonesian state is a constitutional state based on Pancasila and the 1945 Constitution. One manifestation of this concept is the protection of its citizens, such as protection for victims of online gender-based violence (KBGO). This study aims to determine the application of online gender-based violence (KBGO) for the realization of the objectives of punishment and to determine the application of law to perpetrators of online gender-based violence (KBGO) in the perspective of the constitutional state of Pancasila. The approach method used in this research is a conceptual approach or library research methods (library research) and the research specification uses descriptive analytical methods. Based on the results of the research, it shows that KBGO perpetrators who are threatened with imprisonment based on the Criminal Code and / or the ITE Law and / or the Pornography Law do not cause a deterrent effect, therefore the purpose of punishment is a very essential element by referring to the Pancasila principles in accordance with the Indonesian culture. Based on this, the author is of the view that it is important to carry out the reconstruction and reformulation of criminal sanctions in positive law, namely rehabilitation through social work crimes in the context of the realization of the objectives of punishment based on the state law of Pancasila.
\end{abstract}

Keywords: Legal Studies; KBGO; Criminalization; Pancasila

\begin{abstract}
ABSTRAK
Negara Indonesia adalah negara hukum yang berdasar pada Pancasila dan UUD 1945. Salah satu wujud dari konsep tersebut ialah perlindungan terhadap warga negaranya, hal ini diwujudkan dengan adanya perlindungan terhadap korban kekerasan berbasis gender online (KBGO). Penelitian ini bertujuan untuk mengetahui penerapan kekerasan berbasis gender online (KBGO) demi terwujudnya tujuan pemidanaan serta untuk mengetahui penerapan hukum terhadap pelaku kekerasan berbasis gender online (KBGO) dalam perspektif negara hukum Pancasila. Metode pendekatan yang digunakan dalam penelitian ini adalah pendekatan konseptual atau metode library research (penelitian kepustakaan) dan spesifikasi penelitian menggunakan metode deskriptif analitis. Berdasarkan hasil penelitian, menunjukkan bahwa pelaku KBGO yang diancam sanksi pidana penjara berdasarkan KUHP dan/atau UU ITE dan/atau UU Pornografi tidak menimbulkan efek jera, oleh karena itu tujuan pemidanaan merupakan unsur yang sangat esensial dengan merujuk pada sila-sila Pancasila yang sesuai dengan budaya bangsa Indonesia. Berdasarkan hal tersebut, penulis berpandangan bahwa penting dilakukannya rekonstruksi dan reformulasi sanksi pidana dalam hukum positif yaitu rehabilitasi melalui pidana kerja sosial dalam rangka terwujudnya tujuan pemidanaan yang berlandaskan negara hukum Pancasila.
\end{abstract}

Kata Kunci : Kajian Hukum; KBGO; Pemidanaan; Pancasila

\section{PENDAHULUAN}

Perkembangan dan penyebaran teknologi informasi berkembang sangat pesat dapat dilihat dari luasnya jangkauan internet yang bersifat tanpa batas, serta populernya penggunaan media sosial, banyak sekali manfaat internet namun juga memiliki dampak negatif seperti menimbulkan bentuk-bentuk kekerasan 
Fakultas Hukum Universitas Komputer Indonesia

Vol. 3 No. 2 Juli 2021

terhadap perempuan. Bersama dengan meningkatnya kesadaran masyarakat tentang isu-isu kekerasan yang terjadi, mulai dari kekerasan langsung maupun kekerasan online melalui sosial media menghadirkan sebuah istilah baru yaitu KBGO (Kekerasan Berbasis Gender Online). Kekerasan Berbasis Gender ini sudah populer sejak resolusi PBB tahun 1993 tentang deklarasi penghapusan kekerasan terhadap perempuan. Resolusi Majelis Umum No 48/104 tanggal 20 Desember 1993 dalam Pasal 1 yang jika diartikan dalam bahasa Indonesia sebagai berikut "setiap tindakan kekerasan berbasis gender yang mengakibatkan atau kemungkinan akan mengakibatkan kerugian fisik, seksual atau psikologis atau penderitaan bagi perempuan termasuk ancaman tindakan seperti itu paksaan atau sewenang-wenang, pengurangan kebebasan baik yang terjadi didepan umum maupun secara pribadi". 1

KBGO menurut Komisi Nasional Anti Kekerasan pada Perempuan (Komnas Perempuan) yakni kejahatan dengan korban perempuan yang seringkali berhubungan dengan tubuh perempuan yang dijadikan objek pornografi di dunia siber. ${ }^{2}$ Kekerasan yang dilakukan termasuk tindakan yang menimbulkan penderitaan fisik, psikologis, seksual. Komnas Perempuan menemukan adanya lonjakan kasus-kasus KBGO atau ranah kejahatan siber terlebih dimasa pandemi covid-19. Dengan frekuensi pemakaian internet yang meningkat memperbesar resiko dalam penyalahgunaan internet. Menurut data dari lembaga layanan dan pengaduan langsung ke Komnas Perempuan, Jumlah kasus Kekerasan terhadap Perempuan sepanjang tahun 2020 sebesar 299.911 kasus, Jenis-jenis Kekerasan Berbasis Gender yang terjadi di media sosial beragam yang dapat dikelompokan sebagai berikut: pelecehan online, pelanggaran privasi, pendekatan untuk memperdaya, revenge porn, ancaman distribusi foto/video pribadi, pencemaran nama baik, peretasan, impersonasi, dan rekruitmen online. ${ }^{3}$ KBGO mencakup perilaku, termasuk penguntitan, pengintimidasian, pelecehan seksual, pencemaran nama baik, ujaran kebencian, dan eksploitasi. ${ }^{4}$ Hal-hal ini disebabkan karena adanya konstruksi sosial yang keliru dari masyarakat dan terus menerus terlanjur tertanam oleh masyarakat dan dianggap sebagai kebenaran hal-hal yang merupakan ketidakadilan gender. Berbagai bentuk ketidakadilan yang dimaksud, yakni marginalisasi atau proses pemiskinan ekonomi, subordinasi atau anggapan tidak penting dalam keputusan politik, pembentukan stereotipe atau melalui pelabelan negatif, kekerasan (violence), beban kerja lebih panjang dan lebih banyak (burden), serta sosialisasi ideologi nilai peran gender. ${ }^{5}$ Kekerasan terhadap perempuan berakar dari ketidakseimbangan relasi kuasa antara laki-laki dan perempuan. Tidak sedikit pelaku secara tidak sadar melakukan KBGO karena ketidaktahuan dan membudayanya pemahaman patriarkis sehingga mewajarkan tindakan yang menimbulkan korban. Ketentuan yang ada di Indonesia tidak memberikan efek jera bagi pelaku KBGO. Berdasarkan hal tersebut, maka yang menjadi tujuan dari penelitian ini adalah bagaimana penerapan hukum terhadap pelaku kekerasan berbasis gender online (KBGO) dalam perspektif negara hukum Pancasila dan bagaiamana penerapan sanksi kekerasan berbasis gender online (KBGO) demi terwujudnya tujuan pemidanaan.

\section{METODE PENELITIAN}

Penelitian ini menggunakan metode pendekatan yuridis normatif, penelitian yang membahas doktrindoktrin atau asas-asas dalam ilmu hukum. Karena menggunakan data sekunder sebagai data utama. Perolehan data dilakukan melalui studi kepustakaan, yaitu suatu teknik pengumpulan data yang dilakukan melalui

\footnotetext{
${ }^{1}$ Apriyanti Marwah Nucholis, "Mengintip Potensi Meningkatnya Kekerasan Terhadap Perempuan Ditengah Pandemic Covid-19 (Kekerasan Berbasis Gender Offline Dan Online)" (Seminar Online disampaikan dalam rangka memperingati Hari Kartini, Batari Hyang, 2020).

2 Nenden S. Arum, "Mengenal Kekerasan Berbasis Gender Online (KBGO)," Medium, 2019, https://medium.com/@ nendensan/mengenal-kekerasan-berbasis-gender-online-kbgo-a4ec1bd95632.

${ }^{3}$ Jihan Risya et al., "Kekerasan Berbasis Gender Di Media Sosial,” PAMALI: Pattimura MagisterLaw Review 1, no. 1 (2021): 55-61.

${ }^{4}$ Apriyanti Marwah Nucholis, "Mengintip Potensi Meningkatnya Kekerasan Terhadap Perempuan Ditengah Pandemic Covid-19 (Kekerasan Berbasis Gender Offline Dan Online)."

${ }^{5}$ Mansour Fakih, “Analisis Gender Dan Transformasi Sosial” (Yogyakarta: INSISTPress, 2008), 13.
} 
Vol. 3 No. 2 Juli 2021

Fakultas Hukum Universitas Komputer Indonesia

kepustakaan sebagai literatur yang dapat memberikan landasan teori yang relevan dengan masalah yang akan dibahas antara lain dapat besumber dari perundang-undangan yang berlaku di Indonesia. Spesifikasi penelitian ini, peneliti menggunakan metode deskriptif analisis yaitu menggambarkan perundang-undangan dengan teoriteori hukum dalam praktik pelaksanaan hukum positif dan fakta yang ada.

\section{PEMBAHASAN}

\section{Penerapan Hukum Terhadap Pelaku Kekerasan Berbasis Gender Online (KBGO) Dalam Perspektif Negara Hukum Pancasila}

Pasal 1 ayat (3) Undang-Undang Dasar 1945 Amandemen ketiga yang telah ditegaskan bahwa Indonesia adalah Negara Hukum. Dalam kehidupan bernegara, salah satu yang harus ditegakkan adalah suatu kehidupan hukum di dalam kehidupan bermasyarakat. Negara Indonesia adalah negara hukum yang berdasar atas konstitusi. Hal ini berarti bahwa kekuasaan pemerintahnya, hak-hak rakyatnya dan hubungan antara kekuasaan pemerintah dan hak-hak warga negaranya diatur oleh hukum. Negara Indonesia adalah negara hukum yang berdasar atas konstitusi. Hal ini berarti bahwa kekuasaan pemerintahnya, hak-hak rakyatnya dan hubungan antara kekuasaan pemerintah dan hakhak warga negaranya diatur oleh hukum. ${ }^{6}$

Hal ini terlihat dalam pembukaan Undang-Undang Dasar 1945 alinea keempat yang menyatakan bahwa: "kemudian daripada itu untuk membentuk suatu Pemerintah Negara Indonesia yang melindungi segenap bangsa Indonesia dan seluruh tumpah darah Indonesia dan untuk memajukan kesejahteraan umum, mencerdaskan kehidupan bangsa dan ikut melaksanakan ketertiban dunia yang berdasarkan kemerdekaan, perdamaian abadi, dan keadilan sosial.“

Adanya aliran hukum adalah ditentukan oleh masa dan waktu sehingga oleh para ahli hukum membuat penafsiran hukum berdasarkan waktu dan tempat sehingga untuk pada saat ini para ahli hukum selalu mengkaji hukum itu berdasarkan dengan adanya timbul berbagai aliran dalam filsafat hukum menunjukan pergulatan pemikiran yang tidak henti-hentinya dalam lapangan ilmu hukum. Masa lalu, filsafat hukum merupakan produk sampingan dari para filsuf, dewasa ini kedudukannya tidak lagi demikian karena masalah-masalah filsafat hukum telah menjadi bahan kajian tersendiri bagi para ahli hukum. Aliran-aliran filsafat hukum yang akan diterapkan dalam permasalahan yang dibahas adalah positivisme hukum. Aliran positivisme ini pemikiran John Austin, Hans Kelsen dan H. L A. Hart. Secara garis besar pandangan positivisme hukum sebagai norma-norma positif dalam system peraturan perundang-undangan. Pandangan tersebut yang melahirkan landasan dalam paham positivisme modern. Filsafat ilmu hukum memberikan prespektif bahwa keadilan diwujudkan dalam hukum. Filsafat hukum berupaya memecahkan persoalan, menciptakan hukum yang lebih sempurna, serta membuktikan bahwa hukum mampu memberikan penyelesaian persoalan-persoalan yang hidup dan berkembang di dalam masyarakat dengan menggunakan sistim hukum yang berlaku suatu masa, disuatu tempat sebagai Hukum Positif. ${ }^{7}$ Bahwa, ilmu hukum adalah normative, ini berarti bahwa menurut pandangan Hans Kelsen, hukum itu berada dalam dunia Sollen, dan bukan dalam dunia Sein. Sifatnya adalah hipotesis, lahir karena kemauan dan akal manusia. ${ }^{8}$

Berkaitan dengan hal tersebut, jumlah kekerasan terhadap perempuan atau korban setiap tahun mengalami peningkatan dalam berbagai jenis kekerasan yaitu 1248 kasus ditahun 2015, diikuti

\footnotetext{
${ }^{6}$ Sahat Maruli Tua Situmeang, "Kebijakan Kriminal Dalam Penegakan Hukum Untuk Mewujudkan Keadilan Dalam Perpektif Hak Asasi Manusia," Res Nullius 1, no. 1 (2017): 26-36, https://doi.org/10.5749/minnesota/9781517901585.003.0004.

${ }^{7}$ Handayani Handayani, Johannes Satya Pirma, and Kiki Kiki, "Peranan Filsafat Hukum Dalam Mewujudkan Keadilan," Jurnal Muara Ilmu Sosial, Humaniora, Dan Seni 2, no. 2 (2018): 720-25, https://doi.org/10.24912/jmishumsen.v2i2.2572.

${ }^{8}$ LLM. Prof. Dr. Lili Rasjidi, S.H., Filsafat Hukum Apakah Hukum Itu?, Keempat (Bandung: Remaja Rosdakarya Offset, 1988).
} 


\section{Res Nullius \\ Law Journal}

Fakultas Hukum Universitas Komputer Indonesia

Vol. 3 No. 2 Juli 2021

kenaikan ditahun 2016 menjadi 1353 kasus, ditahun 2017 terdapat penurunan 1301, ditahun 2018 turun kembali menjadi 1234 kasus tapi mengalami kelonjakan ditahun 2019 yaitu 1419 kasus. Tahun 2020 meskipun tercatat terjadi penurunan pengaduan korban ke berbagai lembaga layanan dimasa pandemik COVID-19 dengan sejumlah kendala sistem dan pembatasan sosial, Komnas Perempuan justru menerima kenaikan pengaduan langsung yaitu sebesar 2.389 kasus dibandingkan tahun sebelumnya yaitu 1.419 kasus, atau terdapat peningkatan pengaduan 970 kasus (40\%) di tahun $2020 .^{9}$ Data Lembaga Penyedia Layanan menunjukkan bahwa KBGS (Kekerasan Berbasis Gender Siber) atau KBGO menunjukan adanya peningkatan dari 126 kasus di 2019 menjadi 510 kasus pada tahun 2020. Bentuk kekerasan yang mendominasi KBG0 adalah kekerasan psikis $49 \%$ (491 kasus) disusul kekerasan seksual 48\% (479 kasus) dan kekerasan ekonomi 2\% (22 kasus). ${ }^{10}$ Adapun faktor pendorong terjadinya KBGO, antara lain:

1) Ketidakadilan Gender

Pemahaman mengenai ketidakadilan gender merupakan konsep penting yang perlu dipahami dalam membahas masalah yang berkaitan dengan perempuan adalah membedakan antara konsep seks (jenis kelamin) dan konsep gender. Pemahaman dan pembedaan antara konsep seks dan gender sangatlah diperlukan dalam melakukan analisis untuk memahami persoalan-persoalan ketidakadilan sosial yang menimpa perempuan. Hal ini disebabkan karena ada kaitan yang erat antara perbedaan gender dan ketidakadilan gender dengan stuktur ketidakadilan masyarakat secara lebih luas.

Gender adalah sifat dan perilaku yang dilekatkan pada lakilaki dan perempuan yang dibentuk secara sosial maupun budaya. Menurut Ilmu Sosiologi dan Antropologi, Gender itu sendiri adalah perilaku atau pembagian peran antara laki-laki dan perempuan yang sudah dikonstruksikan atau dibentuk di masyarakat tertentu dan pada masa waktu tertentu pula. Dengan kata lain basis gender adalah konstruksi social atau bentukan masyarakat itu sendiri. ${ }^{11}$ Konsep gender melahirkan atau memunculkan dikotomi, sifat, peran, dan posisi yang beragam antara laki-laki dan perempuan. Dikotomi ini meliputi sifat maskulin bagi laki-laki dan sifat feminin bagi perempuan, peran publik untuk laki-laki dan peran domestik untuk perempuan, posisi mendominasi bagi laki-laki dan posisi tersubordinasi bagi perempuan. ${ }^{12}$ Adapun perbedaan antara seks dan gender diuraikan dalam tabel di bawah ini:

Table 1 Perbedaan Seks dan Gender

\begin{tabular}{|c|c|c|c|}
\hline No. & Karakteristik & Seks & Gender \\
\hline 1 & Sumber Pembeda & Pemberian dari Tuhan & $\begin{array}{lll}\begin{array}{l}\text { Pemberian } \\
\text { (Masyarakat) }\end{array} & \text { dari } & \text { Manusia }\end{array}$ \\
\hline 2 & Visi, Misi & Kesetaraan & Kebiasaan \\
\hline 3 & Unsur Pembeda & $\begin{array}{l}\text { Biologis } \\
\text { reproduksi) }\end{array}$ & Kebudayaan (Tingkah laku) \\
\hline 4 & Sifat & Kodrat, tertentu, tidak & martabat, \\
\hline
\end{tabular}

\footnotetext{
9 Komnas Perempuan, "Perempuan Dalam Himpitan Pandemi: Lonjakan Kekerasan Seksual, Kekerasan Siber, Perkawinan Anak, Dan Keterbatasan Penanganan Di Tengah Covid-19," Lembar Fakta Dan Poin Kunci Catatan Tahunan Komnas Perempuan Tahun 2020, 2021, 5-9.

${ }^{10}$ Komnas Perempuan.

${ }^{11}$ Siti Rokhimah, "Patriarkhisme Dan Ketidakadilan Gender," MUWAZAH: Jurnal Kajian Gender 6, no. 1 (2014): 13245.

${ }^{12}$ Yanuarius You et al., "Relasi Gender Patriarki Dan Dampaknya Terhadap Perempuan Hubula Suku Dani, Kabupaten Jayawijaya, Papua," Sosiohumaniora 21, no. 1 (2019): 65-77, https://doi.org/10.24198/sosiohumaniora.v21i1.19335.
} 
Fakultas Hukum Universitas Komputer Indonesia

Vol. 3 No. 2 Juli 2021

\begin{tabular}{|c|l|l|l|}
\hline & & dapat dipertukarkan & dipertukarkan \\
\hline 5 & Dampak & $\begin{array}{l}\text { Terciptanya nilai-nilai : } \\
\text { kesempurnaan, } \\
\text { kenikmatan ke damaian, } \\
\text { menguntungkan kedua } \\
\text { belah pihak }\end{array}$ & $\begin{array}{l}\text { Terciptanya norma-norma } \\
\text { ketentuan tentang "pantas" atau } \\
\text { tidak pantas" }\end{array}$ \\
\hline 6 & Keberlakuan & $\begin{array}{l}\text { Sepanjang masa, dimana } \\
\text { saja tidak mengenal } \\
\text { pembedaan kelas }\end{array}$ & $\begin{array}{l}\text { Dapat berubah, musiman, berbeda } \\
\text { antara kelas. }\end{array}$ \\
\hline
\end{tabular}

Perempuan cenderung mendapatkan berbagai bentuk ketidakadilan gender seperti sub-ordinasi (menomorduakan perempuan), marginalisasi (pemiskinan), stereotype (label negative), double burden (beban ganda), dan kekerasan terhadap perempuan. Dominasi laki-laki merupakan praktik keseharian yang sulit dihapuskan, dan ini sering berakhir pada pelanggaran terhadap hak asasi manusia anak dan perempuan secara sistematis. Kekerasan terhadap perempuan berakar dari ketidakseimbangan relasi kuasa antara perempuan dengan laki-laki. Hal-hal tersebut menimbulkan budaya patriarkis dimana sistem kekeluargaan yang sangat mementingkan garis keturunan laki-laki/bapak. Patriarkhi adalah sebuah sistem sosial yang menempatkan laki-laki sebagai sosok otoritas utama yang sentral dalam organisasi sosial. ${ }^{13}$

2) Psikologis

Menurut hasil wawancara dengan Ibu Nira Wulansari, S.Psi,M.Psi psikolog di Anahata Psikologi Klinik Bandung. Dari perpektif psikologis, faktor pemicu pelaku melakukan kekerasan adalah bahwa pelaku juga merupakan korban dari bentuk ketidakmampuan membela diri yang menjadikan pelakupun melakukan hal yang sama kepada korban. Terbentuk dari faktor lingkungan yaitu keluarga dan menganggap hal yang dilakukan adalah hal yang biasa karena pemahaman keliru yang sudah membudaya dan terakhir adalah terbentuk karena pola kehidupan didukung oleh etika yang kurang.

3) Moral yang kurang

Moral adalah suatu perilaku, tingkah laku, akhlak, budi pekerti yang membentuk karakter diri seseorang sehingga dalam sosialisasi terjalin rasa saling menghormati terhadap sesama. Moral yang kurang menjadikan pelaku menganggap hal biasa terhadap sesuatu hal yang tidak pantas dan tidak baik. Karena setiap perilaku, termasuk perilaku penjahat dilakukan oleh seorang manusia yang hidup dalam situasi kondisi kehidupan tertentu dalam pemikiran kriminilogis positivitis. ${ }^{14}$

4) Pendidikan Seksual yang kurang

Pendidikan mengenai seks di Indonesia masih dianggap tabu. Padahal pentingnya mempelajari seks sejak dini, dapat membentuk pemahaman mengenai hal-hal yang boleh dan tidak boleh dilakukan. Pendidikan seks juga mencegah perilaku seks bebas, kehamilan tidak diinginkan, aborsi, pemerkosaan, hingga penularan penyakit seksual. Faktor-faktor tersebut yang secara sadar ataupun tidak yang mengakibatkan seseorang bisa menjadi pelaku KBGO.

Peraturan perundang-undangan yang mengatur kekerasan terhadap perempuan atau pelecehan terdapat dalam :

1) KUHP

Arti pelecehan diranah hukum hanya dikenal dengan istilah perbuatan cabul sedangkan makna pelecehan dapat lebih luas dari istilah perbuatan cabul yang disebutkan

\footnotetext{
${ }^{13}$ Rokhimah, "Patriarkhisme Dan Ketidakadilan Gender."

${ }^{14}$ Bambang Waluyo, Pidana Dan Pemidanaan, 2014.
} 
Fakultas Hukum Universitas Komputer Indonesia

Vol. 3 No. 2 Juli 2021

dalam KUHP. Bahasa yang lebih tepat untuk menjelaskan pelecehan seksual adalah kekerasan seksual. Kekerasan seksual diatur dalam KUHP Pasal 289 mengenai perbuatan cabul sedangkan pelecehan seksual atau kekerasan seksual memiliki makna lebih luas daripada perbuatan cabul. Salah satu contohnya adalah pelecehan verbal yang dilontarkan dari ucapan seseorang secara keinginan sepihak kepada pihak lain dan kalimat yang dilontarkan mengandung unsur sensual atau merendahkan pihak lain. Dalam kondisi seperti itu, pasal yang dapat diterapkan adalah pasal 335 ayat 1 mengenai perbuatan tidak menyenangkan. Walaupun pasal tersebut belum dapat melindungi perempuan dari pelecehan verbal. Namun dengan berkembangnya teknologi informasi, pelecehan verbal yang dilakukan dengan pengucapan kalimat atau ungkapan langsung beralih berupa teks melalui media sosial atau dikenal dengan istilah sexting atau cyber harrasment yang merupakan salah satu bentuk KBGO.

2) Undang-Undang Nomor 44 Tahun 2008 tentang Pornografi

Pasal 29 mengatur penindakan pelaku penyebaran konten pribadi yang berdampak dapat diaksesnya oleh public.

Karena bagaimanapun penyebaran video intim yang biasanyan menimbulkan public menghakimi orang yang tampil didalamnya merupakan bentuk kekerasan. Sayangnya undang-undang ini bukan hanya melindungi korban jurstru dalam pasal 34 UU Pornografi dapat membuat seseorang didalam konten atau melakukan tindakan pornografi sebagai sasaran untuk dijatuhkan hukum pidana. Ketentuan tersebut menyatakan "setiap orang yang dengan sengaja atau atas persetujuan dirinya menjadi objek atau model yang mengandung muatan pornografi sebagaimana dimaksud dalam pasal 8 dipidana penjara paling lama 10 tahun dan/atau pidana denda paling banyak Rp. 5 Milyar" dalam pasal 8 UU Pornografi sendiri menyebutkan "setiap orang dengan sengaja atau atas persetujuan dirinya menjadi objek atau model yang mengandung muatan pornografi"

3) Undang-Undang Nomor 19 Tahun 2016 perubahan atas Undang-Undang Nomor 11 Tahun 2008 tentang Informasi dan Transaksi Elektronik

Kriminalisasi perbuatan yang termasuk kategori tindak pidana siber sebagaimana diatur dalam Konvensi Dewan Eropa 2001 sebagian sudah diatur dalam Undang-Undang No.11 Tahun 2008 tentang Informasi dan Transaksi Elektronik (UU ITE) Khususnya Bab VII tentang Perbuatan yang dilarang terdapat dalam pasal 27 sampai pasal 37 yang mengatur tindak pidana kesusilaan, perjudian, penghinaan/pencemaran nama baik, pemerasan dan pengancaman, berita bohong dan menyesatkan, menyebarkan kebencian dan permusuhan, illegal acces, illegal interception, data interference, system interference, computer related forgery, dan misuse of devices. Sanksi Pidana atas perbuatan yang dilarang tersebut diatur dalam pasal 45 sampai dengan pasal 52.

Secara garis besar, substansi dalam UU ITE mengatur tentang KBGO yaitu:

1) Pasal 27 (Asusila, perjudian, penghinaan, pemerasan)

2) Pasal 28 (Berita bohong dan menyesatkan, berita kebencian, dan permusuhan)

3) Pasal 29 (Ancaman pemerasan dan menakut-nakuti)

4) Pasal 35 (manipulasi, penciptaan, perubahan, penghilangan, pengrusakan informasi elektronik dan/ atau dokumen elektronik)

Peraturan perundang-undangan diatas seharusnya sudah dapat mengatur untuk menegakan kekerasan terhadap perempuan. Namun banyak jenis kekerasan terhadap perempuan yang belum termasuk kedalam kategori diatas, karena tidak semua jenis KBGO diatur dalam Undang-Undang Informasi Dan Transaksi Elektronik. Seperti, cyberharrasment, cyber grooming dan infringement of privacy yang termasuk kedalam jenis KBGO namun belum ada pasal yang mengaturnya. Sejauh ini, kejahatan asusila dihukum dengan Pasal 45 ayat 1 UU ITE yang menyebutkan bahwa "setiap orang dengan sengaja dan tanpa hak mendistribusikan dan/atau mentransimiskan dan/atau membuat dapat 
Fakultas Hukum Universitas Komputer Indonesia

Vol. 3 No. 2 Juli 2021

diaksesnya informasi elektronik dan/atau dokumen elektronik yang memiliki muatan yang melanggar kesusilaan sebagaimana dimaksud dalam Pasal 27 ayat 1 UU ITE dipidana penjara paling lama enam tahun dan/atau denda paling banyak Rp. 1 miliar."

Dalam hal ini, idealnya Pancasila yang menjadi falsafah bangsa memiliki nilai filosofis dan historis yang tinggi sebagai Ideologi Negara. Pancasila berisikan asas Ketuhanan Yang Maha Esa, asas kemanusiaan yaitu manusia yang adil dan beradab, asas kebangsaan yaitu persatuan Indonesia, asas kerakyatan yang diimplementasikan kedaulatan rakyat yang berbentuk demokrasi yaitu kerakyatan yang dipimpin oleh hikmat kebijaksanaan dalam permusyawaratan/perwakilan, serta asas keadilan sosial untuk kepentingan umum yaitu keadilan sosial bagi seluruh rakyat Indonesia. Sehingga ini menjadikan Pancasila sebagai penguji hukum positif yang ada di Indonesia, hukum yang ada harus mencakup nilai-nilai yang ada dalam Pancasila. Indonesia merupakan Negara Hukum sebagaimana Pasal 1 ayat 3 UUD 1945 maka dari itu segala perilaku hendaknya tunduk pada ketentuan yang berlaku di Indonesia bagi setiap subjek hukum dimana perilaku yang menyimpang dan melanggar ketentuan akan dikenakan sanksi. Didalam negara hukum juga berisikan asas kepastian hukum, yang tentunya memberikan legalitas yang tinggi dalam menjalankan aturan hukum, dimana legalitas merupakan sebuah nilai inti, hak asasi manusia, dalam arti nullum crimen, nulla poena sine lege (Tidak ada kejahatan, tak ada hukuman tanpa hukum). ${ }^{15}$ Senada dengan asas legalitas yang terdapat dalam pasal 1 KUHP, penerapan hukum KBGO dalam perspektif negara hukum Pancasila, diuraikan sebagai berikut:

1) Berdasarkan Ketuhanan Yang Maha Esa

Ketuhanan Yang Maha Esa memiliki makna Tuhan. Realisasinya dilihat dari nilai-nilai agama. Sehingga dalam melaksanakan hukum positif di Indonesia harus terukur dan disesuaikan dengan aturan yang berasal dari Tuhan yang memegang budi pekerti nilai kemanusiaan yang luhur yang sesuai dengan nilai-nilai agama. Karena Indonesia memiliki lima agama yang diakui di Indoesia yaitu Islam, Katolik, Protestan, Hindu, Budha dan Konghucu ditambah lagi penghayat kepercayaan, nilai ketuhanan yang dipakai harus bersifat universal yang mencakup keadilan, kebenaran, kabaikan, kesetaraan, kebebasan, pengampunan, penghukuman dan lainnya. Notonogoro menyatakan: ${ }^{16}$ "isi-arti sila Ketuhanan Yang Maha Esa, yang tidak terikat kepada bentuk Ketuhanan Yang Maha Esa yeng tertentu, akan tetapi tidak memperkosa dari inti dan istilah sila Ketuhanan Yang Maha Esa, dengan kata lain batas-batas daripada inti-isinya harus cukup luas untuk dapat menempatkan senua agama dan kepercayaan di dalamnya". Hukum mengenai KBGO sudah memiliki nilai Ketuhanan Yang Maha Esa dimana sudah terdapat nilai-nilai kemanusiaan untuk melindungi hak hakiki manusia baik untuk pelaku maupun korban.

2) Berdasarkan Kemanusiaan Yang Adil dan Beradab

Kemanusiaan yang adil dan beradab memiliki inti kata manusia. Sila ini membahas mengenai arti kemanusiaan. Sehingga hukum yang dibuat, diterapkan dan dilaksanakan harus mengandung nilai-nilai kemanusiaan didalamnya. Hukum mengenai KBGO sudah berdasarkan nilai-nilai kemanusiaan baik korban maupun pelaku sudah memiliki ketentuan berdasarkan kemanusiaan untuk melindungi hak nya.

3) Berdasarkan Persatuan Indonesia

Indonesia dengan 33 provinsi, yang terdiri dari suku, budaya, bahasa, agama yang memiliki keragaman diharapkan memiliki rasa yang satu dalam berkehidupan, berbangsa dan bernegara. Nilai kesatuan dapat diterapkan dengan rasa toleransi, gotong royong, rasa saling memiliki sebagai satu kesatuan. Hukum harus dapat dijadikan sebagai pemersatu tujuan, nilai dan jiwa masyarakat. Masyarakat juga harus Bersatu memiliki satu pemahaman yang sama dalam kesetaraan dan keadilan gender dalam keberhasilan penerapan hukum KBGO.

\footnotetext{
${ }^{15}$ Made Hendra Wijaya, S.H., "Karakteristik Konsep Negara Hukum Pancasila."

${ }^{16}$ Made Hendra Wijaya, S.H.
} 
Fakultas Hukum Universitas Komputer Indonesia

Vol. 3 No. 2 Juli 2021

4) Berdasarkan Kerakyatan Yang Dipimpin Oleh Hikmat Kebijaksanaan Dalam Permusyawaratan/Perwakilan

Ini berarti seluruh masyarakat di Indonesia berasal dari rakyat dan tujuan ataupun citacitanya diperjuangkan untuk seluruh rakyat di Indonesia. Sehingga dapat terciptanya keseimbangan antara hak dan kewajiban. Agar terbentuknya keseimbangan tersebut, negara Indonesia menggunakan sistem demokrasi Pancasila yaitu musyawarah untuk mencapai mufakat. Di dalam negara hukum Pancasila, segenap hasil dari permusyawarahan pembentukan hukum dan penerapan dan pelaksanaan hukum di Indonesia dipertanggungjawabkan kepada Tuhan Yang Maha Esa dan seluruh bangsa serta masyarakat Indonesia.

5) Berdasarkan Keadilan Sosial Bagi Seluruh Rakyat Indonesia

Keadilan merupakan sesuatu yang bersifat abstrak, tetapi keadilan merupakan tujuan dari setiap masyarakat di Indonesia. Di dalam sila kelima Pancasila berintikan kata adil, yaitu adil yang memiliki sifat universal, atau adil yang sebenarnya yaitu adil yang tidak memihak, dan nilai adil yang ada dan dapat dirasakan oleh semua masyarakat dan bangsa Indoneisa. Nilai keadilan ini diharapkan dalam pembentukan Undang-Undang, dan kebijakan yang dilakukan pemerintah memiliki rasa keadilan dan kesetaraan serta dalam pelaksanaannya dari UndangUndang dan kebijakan pemerintah, serta pelaksanaan badan Peradilan diharapkan dalam penerapannya dilaksanakan dengan setara dan adil dan tidak membedabedakan. Walaupun bentuk keadilan dapat berbeda tergantung dari perspektif yang dilihat.

2. Penerapan Sanksi Kekerasan Berbasis Gender Online (KBGO) Demi Terwujudnya Tujuan Pemidanaan

UNHCR (United Nations High Commissioner for Refugees) menemukan istilah yang merujuk pada definisi kekerasan berbasis gender yang mendefinisikan KBG sebagai kekerasan langsung pada seseorang yang didasarkan atas seks atau gender. Ini termasuk tindakan yang mengakibatkan bahaya atau penderitaan fisik, mental atau seksual, ancaman untuk tindakan tersebut, paksaan dan penghapusan kemerdekaan. ${ }^{17} \mathrm{KBGO}$ sama seperti kekerasan berbasis gender di dunia nyata, tindak kekerasan tersebut harus memiliki niatan atau maksud melecehkan korban berdasarkan gender atau seksual. Jika tidak, maka kekerasan tersebut masuk dalam kategori kekerasan umum di ranah online. ${ }^{18}$ Kekerasan Berbasis Gender Online memiliki banyak bentuk dan jenis sebagaimana diuraikan dalam tabel di bawah ini:

Tabel 2

Bentuk KBGO

\begin{tabular}{|l|l|}
\hline Cybergrooming & $:$ Pendekatan untuk Memperdaya \\
\hline Cyberharrashment & $\begin{array}{l}: \text { Pengiriman Teks untuk Menyakiti/Menakuti/ Mengancam } \\
\text { /Mengganggu }\end{array}$ \\
\hline Hacking & $:$ Peretasan \\
\hline Illegal Content privacy & $:$ Konten Ilegal \\
\hline Infringement of Pelanggaran Privasi \\
\hline Malicious distribution & $:$ Ancaman Distribusi Foto/Video Pribadi \\
\hline
\end{tabular}

17 SAFEnet, "Memahami Dan Menyikapi Kekerasan Berbasis Gender Online: Sebuah Panduan" 2 (2019): 20, https://id.safenet.or.id/wp-content/uploads/2019/11/Panduan-KBGO-v2.pdf.

18 SAFEnet. 
Fakultas Hukum Universitas Komputer Indonesia

Vol. 3 No. 2 Juli 2021

\begin{tabular}{|l|l|}
\hline Online defamation & : Penghinaan/ Pencemaran Nama Baik \\
\hline Revenge Porn & : kontel seksual milik pribadi yang disebarkan \\
\hline
\end{tabular}

Sumber : Panduan KBGO Safenet ${ }^{19}$

Satjipto Raharjo berpendapat bahwa penegakan hukum itu bukan merupakan suatu tindakan yang pasti, yaitu menerapkan suatu tindakan yang pasti yaitu menerapkan hukum terhadap suatu kejadian, yang dapat di ibaratkan menarik garis lurus antara dua titik. ${ }^{20}$ Dalam menegakkan hukum ini, ada tiga tujuan hukum yang harus diperhatikan, yaitu kepastian hukum, kemanfaatan, dan keadilan. Adapun penjelasan mengenai apa yang disampaikan oleh Sudikno Mertokusumo adalah sebagai berikut: ${ }^{21}$

a. Kepastian hukum (Yuridis)

Kepastian hukum menekankan agar hukum atau peraturan itu ditegakkan sebagaimana yang diinginkan oleh peraturannya.

b. Kemanfaatan (Sosiologis)

Masyarakat mengharapkan manfaat dalam pelaksanaan atau penegakan hukum.

c. Keadilan (Filosofis)

Keadilan merupakan keserasian antara kepastian hukum dan kesebandingan hukum. Namun bagaimanapun juga keadilan oleh hukum harus tercipta sebagaimana dasar Pancasila yang merupakan sumber dari segala sumber hukum di Indonesia yang memiliki lima asas moral yakni ketuhanan, kemanusiaan, persatuan, kerakyatan, dan keadilan sosial. ${ }^{22}$

Tujuan hukum akan tercapai jika hukum sudah efektif dilakukan, teori efektivitas hukum menurut Soerjono Soekanto adalah bahwa efektif atau tidaknya suatu hukum ditentukan oleh 5 (lima) faktor, yaitu: $^{23}$

1. Faktor Hukum

Efektivitas suatu hukum dilihat dari faktor hukumnya itu sendiri. Hukum yang dimaksudkan adalah Undang-Undang atau peraturan tertulis yang berlaku umum dan dibuat oleh Pemerintah. Faktor hukum yang dimaksud adalah bermula dari undang-undangnya itu sendiri yang bermasalah. Berdasarkan teori-teori ilmu hukum, dapat dibedakan tiga macam hal mengenai berlakunya hukum sebagai kaidah. Hal itu diungkapkan sebagai berikut: ${ }^{24}$

a) kaidah hukum berlaku secara yuridis, apabila penentuannya didasarkan pada kaidah yang lebih tinggi tingkatannya atau terbentuk atas dasar yang telah ditetapkan;

b) Kaidah hukum berlaku secara sosiologis, apabila kaidah tersebut efektif. Artinya, kaedah dimaksud dapat dipaksakan berlakunya oleh penguasa walaupun tidak diterima oleh warga masyarakat atau kaidah itu berlaku karena adanya pengakuan dari masyarakat;

c) Kaidah hukum berlaku secara filosofis, yaitu sesuai dengan cita hukum sebagai nilai positif yang tertinggi.

2. Faktor Penegakan Hukum

Efektivitas suatu hukum juga dilihat dari faktor penegak hukumnya. Yang dimaksudkan dengan penegak hukum itu adalah pihak-pihak yang langsung maupun tidak langsung terlibat

\footnotetext{
${ }^{19}$ SAFEnet.

${ }^{20}$ Satjipto Raharjo, Sosiologi Hukum : Perkembangan Metode Dan Pilihan Masalah (Yogyakarta: Sinar Grafika, 2002).

${ }^{21}$ Yohana Puspitasari Wardoyo Sulardi, "Kepastian Hukum, Kemanfaatan Dan Keadilan Dalam Perkara Anak," Jurnal Yudisial 8 no 3 (2015): 251-68.

22 Kepastian Hukum, Kemanfaatan, Dan Keadilan Terhadap Perkara Pidana Anak Kajian Putusan Nomor 201/Pid.Sus/2014/PN.Blt

${ }^{23}$ Ria Ayu Novita, Agung Basuki Prasetyo, and Suparno, "Efektifitas Pelaksanaan Undang-Undang Nomor 2 Tahun 1960 Tentang Perjanjian Bagi Hasil Pertanian (Tanah Kering) Di Desa Beringin, Kecamatan Bayan, Kabupaten Purworejo," Diponegoro Law Journal 6, no. 2 (2017): 1-12.

${ }^{24}$ Novita, Prasetyo, and Suparno.
} 
Fakultas Hukum Universitas Komputer Indonesia

Vol. 3 No. 2 Juli 2021

dalam penegakan hukum mulai dari Polisi, Jaksa, Hakim, Komisi, Penasehat Hukum (Advokat) dan hingga petugas-petugas sipir pemasyarakatan. Setiap profesi penegak hukum mempunyai wewenang atau kekuasaan tugas masing-masing. ${ }^{25} \mathrm{Di}$ dalam berfungsinya hukum,mentalitas atau kepribadian petugas penegak hukum memainkan peranan penting, kalau peraturan sudah baik, tetapi kualitas petugas kurang baik, ada masalah. Oleh karena itu, salah satu kunci keberhasilan dalam penegakan hukum adalah mentalitas atau kepribadian penegak hukum. ${ }^{26}$ Demi mewujudkan keadilan dan kepastian hukum, komponen sistem peradilan pidana yang terdiri dari kepolisian, kejaksaan, pengadilan, Lembaga pemasyarakatan dan penasihat hukum harus memiliki aspek penting dalam penegakan hukum. Aspek penting yang harus terpenuhi dalam rangka mewujudkan sistem peradilan pidana terpadu, adalah: ${ }^{27}$

a. Koordinasi adalah mekanisme penting yang harus terbina dengan baik dalam sistem peradilan pidana terpadu yaitu koorinasi antar segenap aparat penegak hukum;

b. Profesionalitas adalah sistem peradilan pidana terpadu sulit diwujudkan manakala tidak didukung oleh aparat penegak hukum yang professional;

c. Integritas adalah sistem peradilan pidana terpadu sulit diwujudkan manakala tidak didukung oleh aparat penegak hukum yang memiliki integritas.

3. Faktor Sarana atau Fasilitas Pendukung

Efektivitas suatu hukum dilihat dari faktor sarana dan fasilitas, faktor sarana atau fasilitas pendukung mencakup perangkat lunak dan perangkat keras, salah satu contoh perangkat lunak adalah pendidikan.

a) Faktor Masyarakat

Efektivitas suatu hukum dilihat dari faktor masyarakat. Salah satu faktor yang mengefektifkan suatu peraturan adalah warga masyarakat. Yang dimaksud di sini adalah kesadarannya untuk mematuhi suatu peraturan perundang-undangan, yang kerap disebut derajat kepatuhan.

b) Faktor Kebudayaan

Efektivitas suatu hukum dilihat dari faktor Kebudayaan. Kebudayaan Indonesia didasari hukum adat. Hukum adat tersebut merupakan hukum kebiasaan yang berlaku di kalangan rakyat terbanyak

Pada dasarnya hukum pidana memang berfokus pada pengaturan tentang masalah kejahatan yang terjadi di tengah masyarakat. Hukum pidana menjadi penjaga agar masyarakat terhindar dari kejahatan. Pidana menurut Prof. Roeslan Saleh, S.H adalah reaksi atas delik yang banyak berwujud suatu nestapa yang dengan sengaja ditimpakan negara pada pembuat delik. ${ }^{28}$ Tindak pidana diartikan sebagai perbuatan atau tindakan yang memenuhi unsur-unsur rumusan delik yang dimuat di dalam peraturan perundang-undangan. ${ }^{29}$ Dengan demikian pidana adalah merupakan perlindungan terhadap masyarakat dan pembalasan terhadap perbuatan melanggar hukum. Selain itu pidana mengandung hal-hal lain yaitu diharapkan sebagai sesuatu yang akan membawa kerukunan dan pidana adalah suatu proses pendidikan untuk menjadikan orang dapat diterima kembali dalam masyarakat. ${ }^{30}$ Sudah umum diketahui bahwa tindak pidana merupakan pelanggaran atas kepentingan negara sebagai representasi kepentingan publik. Hal ini kemudian menjadi dasar kewenangan bagi negara untuk menentukan, membuat peraturan, menuntut, dan menghukum seseorang yang melanggar peraturan/hukum pidana. Hal ini diperkuat oleh

\footnotetext{
${ }^{25}$ Agus Riyanto, "Penegakan Hukum Masalahnya Apa?,” 2018, https://business-law.binus.ac.id/2018/12/26/penegakanhukum-masalahnya-apa/.

${ }^{26}$ Novita, Prasetyo, and Suparno, "Efektifitas Pelaksanaan Undang-Undang Nomor 2 Tahun 1960 Tentang Perjanjian Bagi Hasil Pertanian (Tanah Kering) Di Desa Beringin, Kecamatan Bayan, Kabupaten Purworejo."

${ }^{27}$ Sahat Maruli Tua Situmeang, "Penahanan Tersangka," edisi revi (Bandung: Logoz Publishing, 2019), 23.

${ }^{28}$ Bambang Waluyo, Pidana Dan Pemidanaan (Jakarta: Sinar Grafika, 2014).

${ }^{29}$ Bambang Waluyo, Pidana Dan Pemidanaan (Jakarta: Sinar Grafika, 2014).

30 Sri Wulandari, "Efektifitas Sistem Pembinaan Narapidana Di Lembaga Pemasyarakatan Terhadap Tujuan Pemidanaan," HUKUM DAN DINAMIKA MASYARAKAT 9, no. 2 (2012): 131-42.
} 
Fakultas Hukum Universitas Komputer Indonesia

Vol. 3 No. 2 Juli 2021

pengklasifikasian ilmu hukum di mana hukum pidana adalah bagian dari hukum publik yang tidak membolehkan campur tangan individu. ${ }^{31}$ Tindak pidana dilakukan secara konvensional menggunakan fisik dan pikiran seperti penipuan, pencurian dan perusakan, kesusilaan, berubah dan beralih menjadi tindak pidana yang dilakukan dengan memanfaatkan sarana cyber. ${ }^{32}$ Kondisi transisi dari bentuk kejahatan konvensional kepada kejahatan siber mendorong para pakar hukum khususnya pidana untuk berusaha mengembangkan hukum pidana agar tetap harmoni dalam masyarakat.

Hakikat hukum menurut Pancasila adalah hukum yang berketuhanan, berkemanusiaan, mengutamakan persatuan dan kejayaan Indonesia, berkerakyatan, dan tentunya berkeadilan. Selain itu, Pancasila adalah etika yang menjadi tolok ukur untuk dapat disebut sebagai "manusia Indonesia yang seutuhnya". Manusia Indonesia yang seutuhnya adalah manusia yang memenuhi hukum keindonesiannya. Hukum keindonesiaan ini pula yang menuntun bangsa Indonesia dalam bersikap dan bertindak, baik kepada sesama maupun lingkungannya. ${ }^{33}$ Di Indonesia kita menganut negara hukum sesuai dengan pasal 1 ayat 3 UUD NRI Tahun 1945, yang menyatakan Negara Indonesia adalah Negara Hukum, yang mana negara hukum yang diharapkan diterapkan adalah negara hukum Pancasila, yaitu negara hukum yang berdasarkan atas kelima sila dari Pancasila yaitu:

1) Ketuhanan Yang Maha Esa;

2) Kemanusiaan Yang Adil Dan Beradap;

3) Persatuan Indonesia;

4) Kerakyatan Yang Dipimpin Oleh Hikmat Kebijaksanaan Dalam Permusyawaratan/ Perwakilan;

5) Keadilan Sosial Bagi Seluruh Rakyat Indonesia.

Hal tersebut dikarenakan Pancasila merupakan jiwa dan falsafah dari hukum dan kehidupan berbangsa di Indonesia yang berasal dari jiwa bangsa Indonesia. selain itu Pancasila juga sebagai tolak ukur bagi segala kegiatan kenegaraan, kemasyarakatan, dan perorangan yang menyangkut berkesusilaan atau bernilai etika. ${ }^{34}$ Penerapan sanksi KBGO dalam Penegakan hukum hakikatnya merupakan upaya menyelaraskan nilai-nilai hukum dengan merefleksikan bersikap dan bertindak demi terwujudnya demi terwujudnya tujuan pemidanaan dengan menerapkan sanksi-sanksi. Sejalan dengan perkembangan peradaban manusia, hukum tidak bersifat statis, tetapi bersifat dinamis yang dipengaruhi terus-menerus sesuai dengan kebutuhan dan kemauan masyarakat. Sistem hukum yang sesuai di Indonesia adalah sistem hukum yang dilandasi oleh nilai- nilai kehidupan dan kebudayaan bangsa Indonesia, yaitu Pancasila sebagai dasar falsafah bangsa dan negara. Dengan demikian, tatanan sistem hukum nasional harus mengacu pada cita hukum Pancasila. ${ }^{35}$ Sebelum mengetahui penerapan sanksi KBGO yang sesuai demi terwujudnya tujuan pemidanaan, harus diketahui terlebih dahulu kendala-kendala dalam penegakan hukum diantaranya dapat dilihat dari unsur-unsur sebagai berikut:

1) Hukum Positif

Hukum Positif di Indonesia seperti KUHP, Undang-Undang Nomor 44 Tahun 2008 tentang Pornografi, dan Undang-Undang Nomor 19 Tahun 2016 perubahan atas Undang-Undang Nomor 11 Tahun 2008 tentang Informasi dan Transaksi Elektronik sudah cukup untuk mengatur KBGO namun hukum yang ada belum menimbulkan efekjera bagi pelaku KBGO.

2) Penegak Hukum

\footnotetext{
31 vivi ariyanti, "Kebijakan Penegakan Hukum Dalam Sistem Peradilan Pidana Indonesia," Jurnal Yuridis 6, no. 2 (2019): 33-54.

${ }^{32}$ Sy. Hasyim Azizurrahman, "Pembaharuan Kebijakan Penegakan Hukum Pidana Di Era 'Cyber," Indonesian Journal of Criminal Law and Criminology 1, no. 2 (2020): 298-305, https://doi.org/10.14710/mmh.41.2.2012.298-305.

33 Tommy Leonard, "Pembaharuan Sanksi Pidana Berdasarkan Falsafah Pancasila Dalam Sistem Hukum Pidana Di Indonesia," Yustisia 5, no. 2 (2016): 468-83.

${ }^{34}$ M.H. Made Hendra Wijaya, S.H., “Karakteristik Konsep Negara Hukum Pancasila,” Jurnal Advokasi 5, no. 2 (2015): 199-214.

${ }^{35}$ Leonard, "Pembaharuan Sanksi Pidana Berdasarkan Falsafah Pancasila Dalam Sistem Hukum Pidana Di Indonesia."
} 
Fakultas Hukum Universitas Komputer Indonesia

Vol. 3 No. 2 Juli 2021

Untuk keberhasilan penegakan hukum perlu adanya harmonisasi dari para aparat penegak hukum di Indonesia. Dimulai dari Polisi, Jaksa, Hakim, dan Advokat.

\section{Kepolisian}

Faktor para penegak hukum kesulitan menegakan hukum KBGO terutama pihak kepolisian diantaranya:

a) Sumber daya manusia yang kurang

Anggota Kepolisian yang ada tidak sebanding dengan laporan yang masuk kepihak kepolisian. Jika dilihat dari lingkup Jawabarat, Menurut wawancara bersama anggota Subdit V Siber Polda Jawa Barat, Bapak Hilman Nukas terdapat 4 unit yang terdiri dari sekitar 44 orang anggota polisi. Hal itu tidak sebanding dengan banyaknya Laporan Polisi yang masuk.

b) Kesiapan mental penegak hukum;

Kesiapan mental disini berfokus kepada, penegak belum memiliki pemahaman yang sama mengenai keadilan gender dan urgensinya kekerasan terhadap perempuan dalam hal ini KBGO. Dimulai dari ranah kepolisian, polisi yang menjadi garda terdepan yang langsung berhadapan langsung dengan masyarakat. Para penegak hukum harus memiliki paham keadilan gender untuk menangani kasus-kasus mengenai kekerasan terhadap perempuan. Baik itu polisi, jaksa, pengacara dan hakim harus memiliki paham keadilan dan gender. Karena dengan paham keadilan gender akan merubah perspektif penanganan kasus kekerasan terhadap perempuan apapun khususnya KBGO.

c) Alat penunjang menegakan hukum yang masih minim.

Untuk menegakan kejahatan siber diperlukan alat khusus untuk menunjang keberhasilan suatu perkara. Masih terbatasnya alat di Subdit V Siber Polda Jawa Barat juga mempengaruhi proses penegakan hukum KBGO. Dengan segara kekurangan dan keterbatasan para penegak hukum diharapkan tetap maksimal dalam menegakan hukum dan keadilan karena bagaimanapun para penegak hukum menjadi ujung tombak perubahan.

\section{Kejaksaan}

Kejaksaan pun berperan dalam penegakan hukum kekerasan terhadap perempuan. Menurut Surat Edaran Jaksa Agung Republik Indonesia Nomor: SE007/A/JA/11/2011 Tentang Penanganan Perkara Tindak Pidana Kekerasan Terhadap Perempuan yang diinstruksikan agar dilaksanakan oleh Kepala Kejaksaan Tinggi, Kepala Kejaksaan Negeri dan Kepala Cabang Kejaksaan Negeri di seluruh Indonesia. Kejaksaan bekerjasama dengan forumforum perlindungan kekerasan terhadap perempuan agar terciptanya keadilan dan kepastian hukum.

\section{Hakim}

Hakim dengan wewenang yang diberikan oleh undang-undang yang menerima, memeriksa bahkan memutus suatu perkara harus memiliki cara pandang kesetaraan dan keadilan gender agar putusan yang diberikan dapat memberikan rasa keadilan.

\section{Advokat \\ Peran advokat juga dinilai sangat penting dalam menegakan hukum dan keadilan di Indonesia. Sudah banyak advokat yang merangkap sebagai aktivis perempuan dibuktikan dengan adanya Asosiasi Perempuan Indonesia untuk Keadilan (APIK) didirikan oleh 7 (tujuh) pengacara perempuan di Jakarta pada 1995. Dalam perkembangannya, anggota APIK dari berbagai daerah mendirikan LBH (Lembaga Bantuan Hukum) APIK yang hingga saat ini berjumlah 16 kantor yang tersebar di seluruh Indonesia.}


Fakultas Hukum Universitas Komputer Indonesia

Vol. 3 No. 2 Juli 2021

\section{Lembaga pemasyarakatan}

Lembaga pemasyarakatan harus memiliki peran agar tidak terjadinya residivis. Sistem pemasyarakatan saat ini dirasa belum tepat untuk mengatasi permasalahan ini. Hal ini disebabkan oleh Kesadaran hukum merupakan kesadaran diri tanpa adanya paksaan dan tekanan maupun perintah untuk tunduk pada hukum yang berlaku. Dengan berjalannya kesadaran hukum di masyarakat maka hukum tidak perlu menjatuhkan sanksi. Proses menegakkan hukum ini, agar tujuan hukum dapat tercapai yaitu kepastian hukum, kemanfaatan, dan keadilan. Masyarakat yang mengimplemantasikan nilai-nilai Pancasila dalam kehidupanya akan memiliki kesadaran hukum. Budaya akan kesadaran hukum yang kurang menjadi kendala dalam penegakan hukum.

Upaya pemberantasan kejahatan berkenaan dengan upaya penegakan hukum dengan memformulasikan peraturan perundang-undangan hukum pidana yang dikenal dengan kebijakan kriminalisasi merupakan kebijakan kriminal yang integral dengan usaha perlindungan masyarakat, sehingga kebijakan hukum pidana merupakan bagian integral dari kebijakan sosial dalam penegakan hukum yang bermakna sebagai segala usaha yang rasional untuk mencapai kepastian hukum, kesejahteraan dan perlindungan masyarakat. Barda Nawawi Arief mengemukakan "Kebijakan kriminalisasi merupakan suatu kebijakan dalam menetapkan suatu perbuatan yang semula bukan tindak pidana (tidak dipidana) menjadi suatu tindak pidana (perbuatan yang dapat dipidana). Hakekatnya kebijakan kriminalisasi merupakan bagian dari kebijakan criminal dengan menggunakan sarana hukum pidana sehingga termasuk bagian dari kebijakan hukum pidana". ${ }^{36}$ Demi terciptanya ke efektivitasan penerapan sanksi KBGO dimana hukum yang mengatur sudah ada, instrument penegak hukum sudah ada walaupun kesadaran masyarakat akan hukum masih sulit dicapai namun dengan dua unsur tersebut seharusnya penegakan hukum tetap dapat berjalan efektif walaupun banyak mengalami kendala. Namun nyatanya, masih tidak menimbulkan efek jera walaupun dalam kehidupan bersosial sanksi sosial sudah pasti ada namun tidak membuat pelaku untuk tidak melakukanya lagi. Artinya, sistem pemidanaan di Indonesia dinilai tidak berhasil, dikarenakan tidak memberikan jaminan bahwa pelaku tidak akan mengulangi perbuatanya kembali atau berpotensi residivis. Dalam penerapan sanksi KBGO ini, peran lembaga masyarakat dinilai berpotensi untuk menegakan hukum. Suatu pembinaan merupakan cara dan usaha yang diupaya kan untuk merubah suatu pola ataupun tatanan. Pembinaan adalah setiap usaha untuk mendidik, membimbing dan mengarahkan sesuatu kegiatan dengan berbagai cara dan usaha melalui suatu proses yang tertib dan teratur rapi untuk mencapai tujuan secara maksimal. Sebagaimana dinyatakan dalam Pasal 5 Undang-Undang Nomor 12 Tahun 1995 tentang Pemasyarakatan sebagai berikut: ${ }^{37}$

1) Pengayoman, adalah perlakuan terhadap warga binaan pemasyarakatan dalam rangka melindungi masyarakat dari kemungkinan diulanginya tindak pidana oleh warga binaan pemasyarakatan, juga memberikan bekal hidup kepada warga binaan pemasyarakatan agar menjadi warga yang berguna di dalam masyarakat;

2) Persamaan perlakuan dan pelayanan, adalah pemberian perlakuan dan pelayanan yang sama kepada warga binaan pemasyarakatan tanpa membedabedakan orang;

3) Pendidikan dan pembimbingan adalah bahwa penyelenggaraan pendidikan dan bimbingan dilaksanakan berdasarkan Pancasila, antara lain penanaman jiwa kekeluargaan, ketrampilan, pendidikan, kerohanian dan kesempatan untuk menunaikan ibadah;

4) Penghormatan harkat dan martabat manusia, adalah bahwa sebagai orang yang tersesat warga binaan pe masyarakatan harus tetap diperlakukan sebagai manusia;

5) Kehilangan kemerdekaan merupakan satu-satunya penderitaan, adalah warga pemasyarakatan harus berada dalam LAPAS untuk jangka waktu tertentu, sehingga negara mempunyai kesempat an untuk memperbaikinya;

\footnotetext{
${ }^{36}$ Hasyim Azizurrahman, "Pembaharuan Kebijakan Penegakan Hukum Pidana Di Era 'Cyber.”'

${ }^{37}$ Wulandari, "Efektifitas Sistem Pembinaan Narapidana Di Lembaga Pemasyarakatan Terhadap Tujuan Pemidanaan."
} 
Fakultas Hukum Universitas Komputer Indonesia

Vol. 3 No. 2 Juli 2021

6) Terjaminnya hak untuk tetap berhubungan dengan keluarga dan orang-orang tertentu, adalah bahwa walaupun warga binaan pemasyarakatan berada di LAPAS, tetapi harus dekat dan dikenalkan dengan masyarakat dan tidak boleh diasingkan dari masyarakat, antara lain berhubungan dengan masyarakat dalam bentuk kunjungan, hiburan ke LAPAS dari anggota masyarakat yang bebas dan kesempatan berkumpul bersama sahabat dan keluarga seperti program cuti mengunjungi keluarga.

Senada dengan pandangan Muladi, yang menyatakan bahwa tujuan dari sistem peradilan pidana bersifat jangka pendek berupa resosialisasi pelaku tindak pidana, bersifat menengah berupa pengendalian kejahatan, dan jangka panjang berupa kesejahteraan sosial. Maka, apabila dilihat dari sistem peradilan pidana terpadu (Integrated Criminal Justice System), pelaksanaan pidana dengan menerapkan sistem pemasyarakatan, merupakan salah satu sub-sistem yang saling berkaitan dengan sub-sistem lainnya. Sistem pemasyarakatan sebagai pelaksanaan pidana penjara, berpegang pada asumsi bahwa arti pemasyarakatan adalah memasyarakatkan kembali narapidana sehingga menjadi warga baik dan berguna atau healthy reentry into the community, yang pada hakikatnya adalah resosialisasi. Oleh karena itu, keberhasilan pembinaan pelaku tindak pidana tidak dimulai sejak dia masuk pintu gerbang lembaga pemasyarakatan, tetapi bahkan pengalaman sejak diperiksa oleh polisi akan mempengaruhi keberhasilan resosialisasi. ${ }^{38}$ Dengan demikian, seharusnya hukuman (sanksi pidana) mempunyai tujuan sebagai berikut: ${ }^{39}$

1) Resosialisasi pelanggar hukum, yakni untuk memungkinkan pelanggar dapat berpartisipasi lagi dalam proses-proses interaksi kemasyarakatan. Dalam hal ini, hukuman ditujukan untuk mengendalikan ketaatan orang yang telah melanggar hukum sehingga dapat direintegrasikan dalam masyarakat. Tujuan ini disebut juga tujuan reformatif.

2) Melindungi masyarakat dan para warganya. Tujuan hukuman yang dikemukakan tadi didasarkan pada asumsi bahwa hukuman juga melibatkan interaksi antara individu (warga masyarakat) dan masyarakat. Oleh karena itu, hukuman harus memperhitungkan juga hari esok pelanggar (delinquent) dan masyarakat.

\section{KESIMPULAN}

Penerapan hukum terhadap pelaku KBGO harus tetap berpedoman terhadap nilai-nilai yang terkandung dalam Pancasila seperti nilai ketuhanan, kemanusiaan, persatuan, kerakyatan dan keadilan. Penggunaan nilai Pancasila dalam pembaruan sanksi pidana di Indonesia, karena nilai tersebut sudah tumbuh bersama dalam masyarakat Indonesia. Dalam penerapan sanksi KBGO demi terwujudnya tujuan pemidanaan yang efektif terdapat dua kebijakan penal dalam penanggulangan KBGO yakni menjalankan sistem peradilan pidana terpadu berkeadilan gender dan pembaharuan peraturan hukum. Menjalankan sistem peradilan pidana berkeadilan gender dengan cara melibatkan korban secara aktif dalam proses penanganan perkara. Terlebih perlu juga peran lembaga pemasyarakatan agar menimbulkan efek jera. Rehabilitasi dengan menanamkan pembinaan Pancasila dan keadilan gender dirasa dapat menjadikan sistem penghukuman yang tepat demi terwujudnya tujuan pidana mencegah dilakukannya tindak pidana dengan menegakan norma hu kum demi pengayoman masyarakat, memasyarakatkan terpidana dengan mengadakan pembinaan sehingga menjadi orang yang baik dan berguna, menyelesaikan konflik yang ditimbulkan oleh tindak pidana, memulihkan keseimbangan dan mendatangkan rasa damai dalam masyarakat dan membebaskan rasa bersalah pada terpidana.

\footnotetext{
${ }^{38}$ Ismail Rumadan, "Problem Lembaga Pemasyarakatan Di Indonesia," Jurnal Hukum Dan Peradilan 2, no. 2 (2013): 264-76.

${ }^{39}$ Leonard, "Pembaharuan Sanksi Pidana Berdasarkan Falsafah Pancasila Dalam Sistem Hukum Pidana Di Indonesia."
} 
Fakultas Hukum Universitas Komputer Indonesia

Vol. 3 No. 2 Juli 2021

\section{SARAN}

Keberadaan hukum yang mengatur terkait pelaku KBGO dirasakan belum optimal. Oleh karenanya penting dilakukannya rekonstruksi dan reformulasi sanksi pidana dalam hukum positif melalui rehabilitasi dan penerapan pidana kerja sosial dalam rangka terwujudnya tujuan pemidanaan yang berlandaskan negara hukum Pancasila.

\section{DAFTAR PUSTAKA}

\section{BUKU:}

Bambang Waluyo. Pidana Dan Pemidanaan. Jakarta: Sinar Grafika, 2014.

. Pidana Dan Pemidanaan. Jakarta: Sinar Grafika, 2014.

Prof. Dr. Lili Rasjidi, S.H., LLM. Filsafat Hukum Apakah Hukum Itu? Keempat. Bandung: Remaja Rosdakarya Offset, 1988.

Sahat Maruli Tua Situmeang. "Penahanan Tersangka,” Edisi revi., 23. Bandung: Logoz Publishing, 2019.

\section{JURNAL:}

Apriyanti Marwah Nucholis. "Mengintip Potensi Meningkatnya Kekerasan Terhadap Perempuan Ditengah Pandemic Covid-19 (Kekerasan Berbasis Gender Offline Dan Online).” 2020.

Handayani, Handayani, Johannes Satya Pirma, and Kiki Kiki. "Peranan Filsafat Hukum Dalam Mewujudkan Keadilan.” Jurnal Muara Ilmu Sosial, Humaniora, Dan Seni 2, no. 2 (2018): 720-25. https://doi.org/10.24912/jmishumsen.v2i2.2572.

Hasyim Azizurrahman, Sy. "Pembaharuan Kebijakan Penegakan Hukum Pidana Di Era 'Cyber.”' Indonesian Journal of Criminal Law and Criminology 1, no. 2 (2020): 298-305. https://doi.org/10.14710/mmh.41.2.2012.298-305.

Komnas Perempuan. "Perempuan Dalam Himpitan Pandemi: Lonjakan Kekerasan Seksual, Kekerasan Siber, Perkawinan Anak, Dan Keterbatasan Penanganan Di Tengah Covid-19." Lembar Fakta Dan Poin Kunci Catatan Tahunan Komnas Perempuan Tahun 2020, 2021, 5-9.

Leonard, Tommy. "Pembaharuan Sanksi Pidana Berdasarkan Falsafah Pancasila Dalam Sistem Hukum Pidana Di Indonesia." Yustisia 5, no. 2 (2016): 468-83.

Made Hendra Wijaya, S.H., M.H. "Karakteristik Konsep Negara Hukum Pancasila." Jurnal Advokasi 5, no. 2 (2015): 199-214.

Mansour Fakih. "Analisis Gender Dan Transformasi Sosial,” 13. Yogyakarta: INSISTPress, 2008.

Novita, Ria Ayu, Agung Basuki Prasetyo, and Suparno. "Efektifitas Pelaksanaan Undang-Undang Nomor 2 Tahun 1960 Tentang Perjanjian Bagi Hasil Pertanian (Tanah Kering) Di Desa Beringin, Kecamatan Bayan, Kabupaten Purworejo." Diponegoro Law Journal 6, no. 2 (2017): 1-12.

Risya, Jihan, Cahyani Prameswari, Deassy Jacomina, and Anthoneta Hehanussa. "Kekerasan Berbasis Gender Di Media Sosial." PAMALI: Pattimura MagisterLaw Review 1, no. 1 (2021): 55-61.

Rokhimah, Siti. "Patriarkhisme Dan Ketidakadilan Gender." MUWAZAH: Jurnal Kajian Gender 6, no. 1 (2014): 132-45.

Rumadan, Ismail. "Problem Lembaga Pemasyarakatan Di Indonesia." Jurnal Hukum Dan Peradilan 2, no. 2 (2013): 264-76.

Satjipto Raharjo. Sosiologi Hukum : Perkembangan Metode Dan Pilihan Masalah. Yogyakarta: Sinar Grafika, 2002.

Situmeang, Sahat Maruli Tua. "Kebijakan Kriminal Dalam Penegakan Hukum Untuk Mewujudkan Keadilan Dalam Perpektif Hak Asasi Manusia." Res Nullius 1, no. 1 (2017): 26-36. https://doi.org/10.5749/minnesota/9781517901585.003.0004.

Sulardi, Yohana Puspitasari Wardoyo. "Kepastian Hukum, Kemanfaatan Dan Keadilan Dalam Perkara Anak." Jurnal Yudisial 8 no 3 (2015): 251-68.

vivi ariyanti. "Kebijakan Penegakan Hukum Dalam Sistem Peradilan Pidana Indonesia." Jurnal Yuridis 6, no. 2 (2019): 33-54. 
Vol. 3 No. 2 Juli 2021

Wulandari, Sri. "Efektifitas Sistem Pembinaan Narapidana Di Lembaga Pemasyarakatan Terhadap Tujuan Pemidanaan." HUKUM DAN DINAMIKA MASYARAKAT 9, no. 2 (2012): 131-42.

You, Yanuarius, Enos H. Rusmansara, Johz Mansoben, and dan Agustina Ivone Poli. "Relasi Gender Patriarki Dan Dampaknya Terhadap Perempuan Hubula Suku Dani, Kabupaten Jayawijaya, Papua." Sosiohumaniora 21, no. 1 (2019): 65-77. https://doi.org/10.24198/sosiohumaniora.v21i1.19335.

\section{INTERNET:}

Agus Riyanto. "Penegakan Hukum Masalahnya Apa?," 2018. https://businesslaw.binus.ac.id/2018/12/26/penegakan-hukum-masalahnya-apa/.

Arum, Nenden S. "Mengenal Kekerasan Berbasis Gender Online (KBGO)." Medium, 2019. https://medium.com/@ nendensan/mengenal-kekerasan-berbasis-gender-online-kbgo-a4ec1bd95632.

Direktorat Tindak Pidana Siber (Dittipidsiber). "Statistik Jumlah Laporan Polisi Yang Dibuat Masyarakat." patroli siber, 2021. https://patrolisiber.id/statistic.

SAFEnet. "Memahami Dan Menyikapi Kekerasan Berbasis Gender Online: Sebuah Panduan" 2 (2019): 20. https://id.safenet.or.id/wp-content/uploads/2019/11/Panduan-KBGO-v2.pdf 